\title{
Skystis pleuros ertmėje - diagnostikos problemos
}

\author{
Arvydas Valavičius \\ Klaipėdos universitetinès ligoninès Pulmonologijos skyrius
}

Reikšminiai žodžiai: skystis pleuros ertmėje, tuberkuliozė, širdies nepakankamumas, plaučių arterijų trombinė embolija, pleuros punkcija, torakoskopija.

Santrauka. Straipsnyje nagrinėjama skysčio pleuros ertmèje problema, diagnostika, stebejjimo ir gydymo principai.

Normaliomis sąlygomis skysčio pleuros ertmèje būna apie 1,0-15 ml - jo kiekis reguliuojamas pusiausvyros tarp hidrostatinio ir onkotinio slègio visceralinès bei pasieninès pleuros kraujagyslèse ir limfos drenažo. Dèl ìvairių priežasčiu pusiausvyrai sutrikus, pleuros ertmèje skysčio kiekis didèja. Tiesinėje krūtinès ląstos rentgenogramoje skystị galima matyti, kai jo tūris pasiekia 200-300 ml (1 pav.), o šoninèje (gulimos padèties) esant $100-300 \mathrm{ml}$.

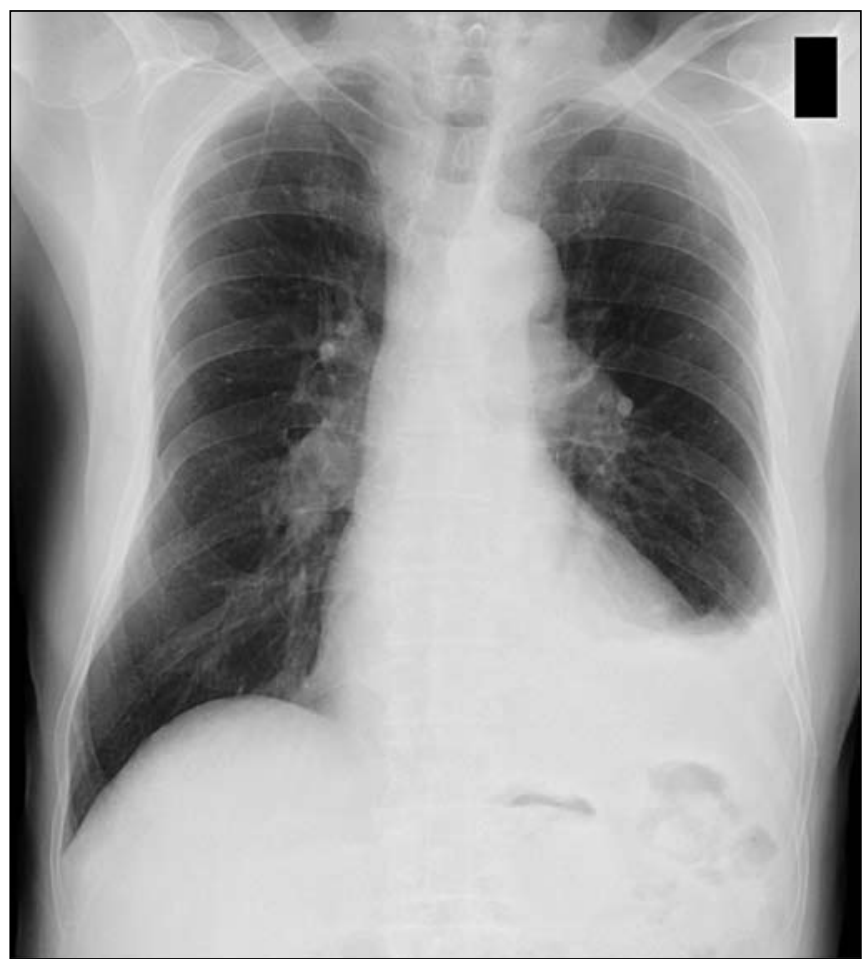

1 pav. Krūtinès priekinè rentgenograma - nedidelis kiekis skysčio kairiojoje pleuros ertmèje
Bet kokiu atveju, skysčio padaugejus, reikia išsiaiškinti ir patikslinti etiologinius veiksnius. Dažniausios skysčio kiekio pleuros ertmèje didejjimo priežastys širdies nepakankamumas, plaučių uždegimas, onkologiniai procesai bei plaučiuc embolija, o mūsų šalyje - ir tuberkuliozè.

\section{MECHANIZMAI, SKATINANTYS SKYSČIO KAUPIMĄSI PLEUROS ERTMĖJE}

Yra keletas mechanizmų skysčiui pleuroje atsirasti:

- Padidejęs pleuros membranų pralaidumas (pvz., uždegimas, onkologinis procesas, plaučiuc trombinė embolija ir kt.);

- Sumažèjęs osmosinis ir koloidinis kraujo slègis (hipoalbuminemija, kepenu cirozė ir kt.);

- Padidejjęs kapiliarų pralaidumas ar kraujagyslių pažeidimai (trauma, onkologinis procesas, infekcija, plaučiu infarktas, jautrumas vaistams, uremija, pankreatitas ir kt.);

- Padidejęs hidrostatinis slègis kapiliaruose, sisteminèje ir plaučių cirkuliacijoje (širdies nepakankamumas, viršutinès $v$. cava spaudimo sindromas ir kt.);

- Sumažèjęs spaudimas pleuros ertmèje (atelektazè, mezotelioma ir kt.);

- Sumažèjęs limfos drenažas ar visiška blokada apimant ir ductus thoracicus (onkologinis procesas, trauma ir kt.);

- Padidèjęs peritoninių skysčių judejjimas per diafragmos limfinius ir struktūrinius defektus (cirozė, peritoninè dializè);

- Skysčių judèjimas per visceralinę pleurą dèl plaučių edemos;

- Nuolat padidèjęs pleuros skysčio onkotinis slègis, kuris skatina toliau kauptis skystị. 


\section{PLEUROS ERTMĖS SKYSČIO KLASIFIKACIJA}

Tradiciškai skystis pleuros ertmèje skiriamas ị transudatą ir eksudatą. Diagnostikos kriterijus, kuriais vadovaujamasi iki šiol daugelyje pasaulio klinikų, 1972 m. paskelbè R. W. Laitas su bendradarbiais (1 lentelè). Laito kriterijų jautrumas siekia 98 proc., o specifiškumas -83 proc.

Manoma, kad transudatas atsiranda dèl onkotinio ir hidrostatinio spaudimo pusiausvyros sutrikimo. Tačiau reikètu nepamiršti, kad galimas ir jatrogeninis skysčio i pleuros ertmę patekimas dèl centrinio veninio kateterio ar nazogastrinio zondo netinkamos lokalizacijos.

Eksudatą dažniau lemia uždegimo būklès, todèl tenka atlikti daug daugiau intervencinių ir gydomụjų procedūrų. Uždegimo procesai skatina ị pleuros ertmę išsiskirti baltymą, o paskui baltymą juda skystis. Jis kaupiasi ir skatina toliau progresuoti procesą. Transudato ir eksudato galimos priežastys nurodomos 2 lenteleje.

\section{PLEUROS ERTMĖS SKYSČIO DIAGNOSTIKA}

Kaip ir kitų ligų atvejais, svarbu įvertinti nurodytas skysčio pleuroje priežastis, kryptingai surinkti anamnezę: persirgtos ar esamos ligas (širdies, inkstų, kepenų ir kt.), darbo ar gyvenimo sąlygos (kontaktas su asbestu ), žalingi ịpročiai (rūkymas, alkoholio ar narkotinių preparatụ vartojimas), krūtinès traumos ar chirurginès procedūros, vartojami, anksčiau vartoti vaistai, galimi navikiniai procesai. Kitas, retesnes ligas galima atmesti jau renkant anamnezę ir grįžti prie jų, jeigu nepatvirtinama nè viena anksčiau minèta pagrindine liga. Taip pat labai svarbu klinikiniu pleurito požymių atsiradimo laikas (po persirgtos pneumonijos, traumos, chirurginès procedūros ar kitu priežasčių).

Klinika dažnai būna „skurdi“ ir išryškejja vèlai nuo pagrindinès ligos vystymosi pradžios, o onkologinių ligų atvejais yra jau vèlyvos stadijos požymis. Pleuritui būdingi trys klinikiniai simptomai: kosulys, dusulys ir pleurinio pobūdžio skausmas. Šie simptomai gali pasireikšti pavieniui ar kartu.

Dažniausias paciento nurodomas požymis - dusulys, kuris atsiranda, kai skysčio kiekis pasiekia daugiau kaip $500 \mathrm{ml}$. Jis pradeda spausti plauti, dèl to sutrinka plaučio judesiai, nepakankamai ikvepiama oro ir progresuoja dusulys. Iš pradžiu jis pasireiškia tik sunkesnio fizinio krūvio metu, vèliau vargina ir esant ramybès būklès. Lèta dusulio progresavimo eiga būdingesnè lètiniams procesams (kiaušidžiu, gimdos, krūtu ir kitu naviku atvejais), o staigus dusulio progresavimas - üminèms ligoms (pneumonijai, PATE ir kt.).

Kosulys gan dažnas, tačiau irgi nepatognominis požymis. Jeigu kartu atkosima ir skrepliu, galima ịtarti plaučiuc uždegimą. Skrepliai su kraujo priemaiša būdingi plaučiuc navikiniam procesui ar tuberkuliozei.

Krūtinès skausmas, ypač prasidedantis staiga, dažniau būna sergant ūminėmis ligomis, kai skystis tiesiogiai dirgina diafragmą. Jo stiprumas gali būti ịvairus: nuo labai
1 lentelè. Laito kriterijai

\begin{tabular}{lll}
\hline Eksudatas & - & $\begin{array}{l}\text { Pleuros skysčio ir kraujo serumo baltymo santykis } \\
\text { didesnis nei 0,5 }\end{array}$ \\
& Pleuros skysčio ir kraujo serumo laktatdehidroge- \\
& nazės (LDH) santykis didesnis nei 0,6 \\
& $\begin{array}{l}\text { Pleuros skysčio LDH aktyvumas didesnis nei } 2 / 3 \\
\text { kraujo serumo LDH aktyvumo viršutinès normos } \\
\text { ribos }\end{array}$ \\
\hline Transudatas & Kai nėra nė vieno eksudatui būdingo kriterijaus
\end{tabular}

2 lentelè. Transudato ir eksudato priežastys

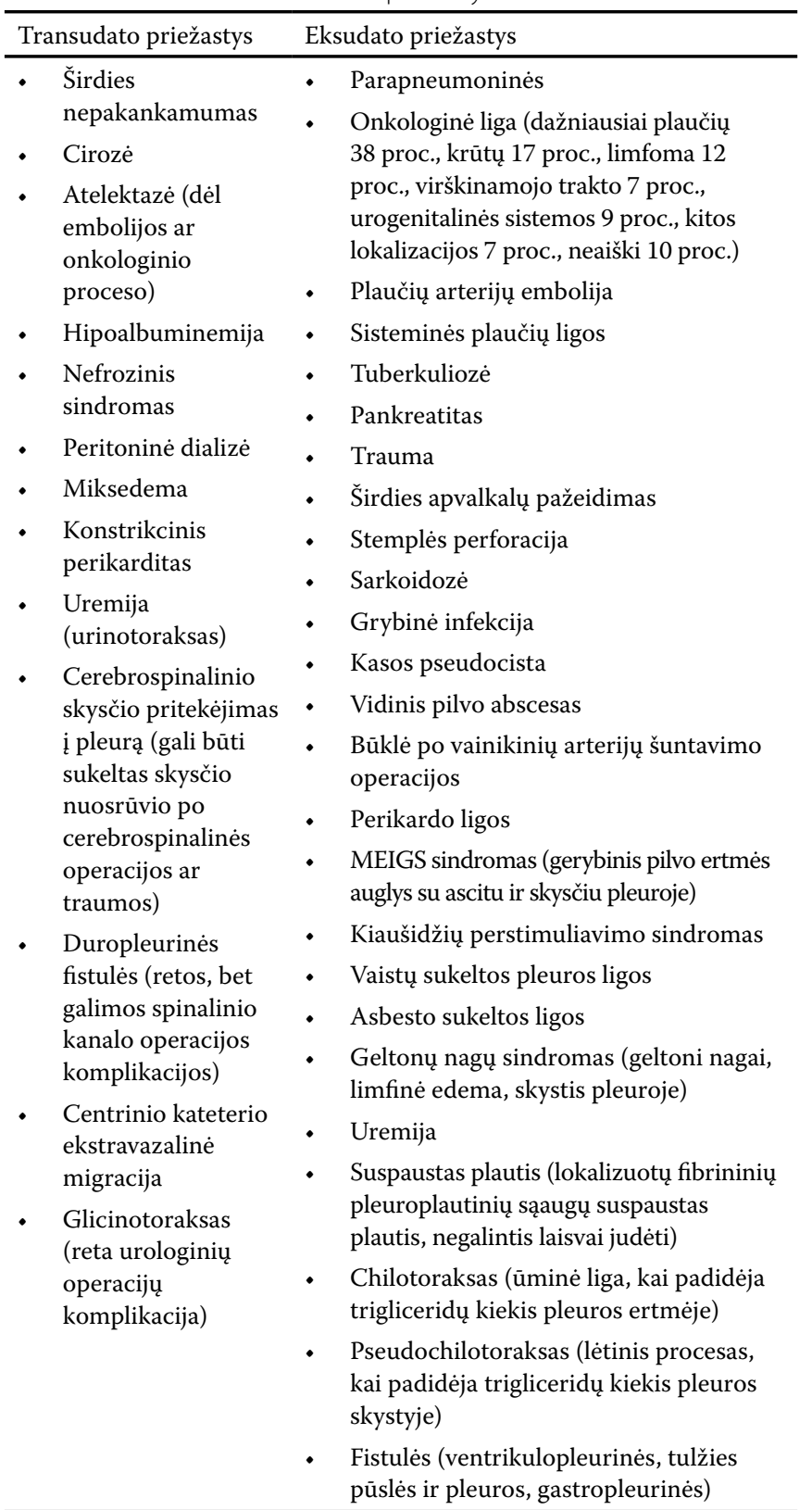

lengvo maudimo iki stipraus kiekvienąkart ikvepiant. Skausmas stipreja didejjant skysčio kiekiui ir atvirkščiai dažniausiai nuslopsta pašalinus visą skystị arba net dalį jo. Tačiau reikia nepamiršti, kad skausmo nebuvimas negali paneigti ịtariamo skysčio pleuros ertmèje. 
Literatūros duomenimis, apžiūros metu pakitimų galima pastebèti, kai skysčio kiekis pleuros ertmèje pasiekia $300 \mathrm{ml}$. Tada perkusijos metu girdèti paduslejęs garsas, susilpnèjęs alsavimas pažeistoje pusẻje (ar išvis jo negirdèti), pleuros trinties garsas, nustatoma periferinè edema, išsiplètusios kaklo venos, padideję limfmazgiai ar čiuopiamos navikinès masès.

Kai skysčio kiekis pasiekia 1000 ml, matyti ị kitą pusę nuo skysčio pasislinkę tarpuplaučio organai, o tarpuplaučio pasislinkimas ì skysčio pusę galimas, kai navikinès masės ar svetimkūnis užkemša skiltinị bronchą.

\section{Pleuros ertmès punkcija}

Pagrindinè diagnostinè procedūra verifikuojant skysčio kilmę yra pleuros ertmès punkcija. Punkcija turi būti atliekama visiems ligoniams, kuriem yra skysčio pleuros ertmejje, išskyrus atvejus, kai skysčio labai nedaug ir punkciją atlikti nèra saugu.

Pleuros ertmès punkcijos komplikacijuc pasitaiko neretai, bet gyvybei jos nepavojingos. Literatūros duomenimis, pneumatoraksas po pleuros ertmès punkcijos pasitaiko $12-30$ proc. atvejų, bet tik apie 5 proc. reikia tolesnių procedūrų (pleuros ertmès drenažo). Labai komplikacijų rizika padidejja, kai punkcija atliekama ligoniams, sergantiems plaučių emfizema dèl LOPL ar kitų ligų. Plaučių audinys būna taip išplonèjęs, kad prisilietusi adata supjausto likusị tinklelị. Tuo atveju pneumatorakso gydymas būna labai ilgas ir kartais tenka operuoti. LOPL ar kitos kilmès emfizema sergančiam ligoniui pleuros punkcija turi būti atliekama labai atsargiai ir pasvėrus galimos naudos ir žalos santykį. Kitais pneumatorakso atvejais užtenka 2-3 dienų orui iš pleuros ertmès pasišalinti per drenažinę sistemą be jokių liekamųjų padarinių. Po pleuros ertmès punkcijos praejjus 1-2 val. rekomenduojama kontrolinè krūtinès ląstos rentgenograma vèlyvajam pneumatoraksui diagnozuoti. Jeigu pneumatoraksas tik pasieninis, ir nèra jokio klinikos pablogèjimo, galima palikti ligoni stebèti. Nedidelis oro kiekis gali rezorbuotis savaime. Kontrolinès rentgenogramos po 2-3 dienų atliekamos norint isitikinti, kad oro kiekis nedideja.

Atlikus pleurito punkciją, pirmiausia vertinamas pleuros skysčio kvapas (dvokiantis būdingas pleuros empiemai, sukeltai anaerobinių bakterijų), spalva, skaidrumas. Nereikètų pervertinti pleuros skysčio spalvos pokyčių. Svarbu kraujingas (hemoraginis pleuritas ir hemotoraksas), pūlingas ar chiliozinis skystis. Rekomenduojama atlikti hematokrito tyrimą. Jeigu jis viršija 50 proc., galimas hemotoraksas, ir reikalingas pleuros ertmès drenažas. Kiti pleuros skysčio atspalviai diferencinès diagnostinès reikšmès neturi.

Kitas pleuros skysčio vertinimo etapas - nustatyti, ar skystis yra transudatas ar eksudatas pagal minètus Laito kriterijus (1 lentelè). Problemų iškyla, kai rodikliai pakitę menkai. Apie 20-25 proc. atvejų transudatas klaidingai palaikomas eksudatu, ypač pacientams, ilgai vartojantiems diuretikų širdies nepakankamumui gydyti (pasikeičia baltymų ir LDH kiekis pleuros ertmèje dėl diurezès). Šiuo atveju eksudatui nuo transudato atskirti siūloma remtis serumo ir pleuros ertmès skysčio skirtu$\mathrm{mu}$, kuris turi būti mažesnis nei $3,1 \mathrm{~g} / \mathrm{dl}$.

Naujiena yra siūlymas širdies nepakankamumo sukeltam skysčiui nustatyti tirti natriurezini peptidą (pro BNP). Išsiaiškinta, kad šio peptido kiekio padidejjimas pleuros ertmejje gali būti širdies nepakankamumo sukeliamo skysčio žymuo. Didesnis nei $1300-4000$ ng/l pro BNP kiekis patvirtina širdies nepakankamumą kaip idiopatinio pleuros ertmès skysčio priežasti, ypač jei tai rodo ir BNP kiekis kraujo plazmoje.

\section{Pleuros ertmès skysčio LDH, gliukozè ir pH}

Atlikus pleuros ertmès punkciją, rekomenduojama ištirti $\mathrm{LDH}$, gliukozès ir $\mathrm{pH}$ rodiklius. Didesnis nei $1000 \mathrm{TV} / \mathrm{l}$ LDH kiekis leidžia ịtarti empiemą, navikinị procesą, reumatoidini artritą.

Maža pleuros skysčio gliukozès koncentracija $(<3,3 \mathrm{mmol} / \mathrm{l})$ ir mažas pleuros skysčio $\mathrm{pH}(<7,3)$ rodo vieną iš keturių dažniausių patologinių būklių: TB, neoplaziją, reumatoidinị artritą ar plaučių uždegimą.

\section{Pleuros ertmès skysčio ląstelinè diferenciacija}

Jeigu pleuros ertmès skystis kliniškai ar pagal tyrimus panašus i eksudatą, rekomenduojama atlikti ląstelių tyrimą (dažymas Gramo būdu, pasèlis ir citologija). Jeigu citologiniame tepinèlyje limfocitų daugiau kaip 85 proc., itariama tuberkuliozè, limfoma, lètinis reumatoidinis pleuritas, geltonų nagu sindromas, chilotoraksas. Jeigu limfocitu yra apie 50-70 proc., galima navikinè liga.

Eozinofilija pleuros ertmès skystyje nustatoma daugiau kaip 10 proc. ligonių, ji nesusijusi su eozinofilu kiekiu pleuros kraujyje. Dažniausia priežastis - oro ar kraujo patekimas ì pleuros ertmę plaučių infarkto metu ar po PATE. Kitos priežastys: parazitinès, grybelinès infekcijos ar vaistai. Kartojant pleuros ertmès punkcijas, eozinofilija gali būti nustatyta ir dèl to, kad kraujo pateko per ankstesnes procedūras. Reikia nepamiršti, kad eozinofilija nei paneigia, nei patvirtina navikinio proceso tikimybę. Apskritai eozinofilijos reikšmė nèra didelè, nes ji būdinga keletui patologijų ir nèra patognominè.

Mezotelio ląstelès nustatomos dauguma tyrimų, jų diagnostinè reikšmė nèra didelè. Manoma, kad TB diagnozè mažai tikètina, jei ju daugiau kaip 5 proc. Ryškai padidèjęs mezotelio ląstelių kiekis kartu su eritrocitais ir eozinofilais leidžia ịtarti, kad skysčio pleuros ertméje atsirado po plaučių arterijos embolijos. Mezotelio ląstelių reikšmė diferencinei diagnostikai nèra didelè.

\section{Pleuros ertmès skysčio pasèlis}

Pleuros ertmės skysčio pasėlis atliekamas, kai įtariama, kad pagrindinès ligos priežastis - infekcija, arba kai atrodo, jog paimtas skystis yra užkrèstas (spalva žalsva, gausu nuosėdų, skystis pūlingas ir pan.). Tačiau pasèlyje neišaugus patogeninių mikroorganizmų, negalima atmesti infekcinès kilmès, nes galejjo būti anaerobai, kurie 
žuvo nuo kontakto su oru imat mėginị ar transportuojant. Pasèliui reikètų siųsti skystị, paimtą vienu dūriu tame pačiame švirkšte, kad nebūtų sąlyčio su aplinkos oru, arba iš karto pasèti ant kraujo kultūrų anaerobines ir aerobines terpès. Tai padidina tikimybę, kad pavyks tiksliai nustatyti sukèlejją.

\section{Navikinis skystis}

Navikinė kilmé dažnai įtariama jau atliekant pleuros punkciją, kai punktatas tamsios spalvos. Nurodoma, kad piktybinių ląstelių randama nuo 60 iki 90 proc. atvejų, priklausomai nuo pirminio proceso kilmés ir lokalizacijos. Esant mezoteliomai, citologinis tyrimas būna teigiamas iki 58 proc. atvejų. Deja, apie 40 proc. atvejų esant onkologiniam procesui piktybinių ląstelių nerandama. Taigi onkologinis procesas patvirtinamas jų radus, bet neradus - atmesti negalima. Tamsios spalvos punktatas turètų būti heparinizuotas (1 $\mathrm{ml} \mathrm{1:1000} \mathrm{heparino} \mathrm{i}$ $50 \mathrm{ml}$ pleuros skysčio) ir centrifuguojamas per vieną valandą nuo paémimo. Tyrimui atlikti reikia apie 150 ml skysčio.

\section{Tuberkuliozinis pleuritas}

Tuberkuliozinę pleurito kilmę nustatyti sunku. Itariama, kai asmens, sirgusio tuberkulioze anksčiau ar turinčio kontaktą su tuberkulioze sergančiu ligoniu, pleuros ertmès skystyje randama daug limfocitu (daugiau kaip 85 proc.) ir mažiau kaip 5 proc. mezotelio ląstelių. Tačiau patvirtinti sunku, jeigu nepavyksta išskirti pačių mikobakterijų iš kvẻpavimo takų. Manoma, kad skysčio sergant tuberkulioze atsiranda dèl hipererginès reakcijos ị sukèlèją, o ne dèl pačių bakterijų invazijos ì pleuros ertmę. Literatūros duomenimis, rūgščiai atsparių bakterijų pleuros ertmeje tuberkuliozès atvejais nustatoma mažiau kaip 10 proc., o pasèlyje išauga mažiau kaip 65 proc. atvejų. Diagnozuojant gan neretai tenka pasitelkti ir intervencines procedūras (pleuros biopsiją vaizdo torakoskopijos metu ir citologinis tyrimas). Šio tyrimo specifiškumas pasiekia 90 proc., bet vis tiek netgi 10 proc. atvejų tuberkuliozinè pleuros skysčio kilmė lieka nediagnozuota.

Bandoma naudoti biocheminius ir imuninius žymenis, bet kol kas dideliu rezultatu nepasiekta, o tyrimai sudetingi ir brangūs. Nurodoma, kad pleuros skysčio adenozindenazès (ADA) (biocheminis žymuo) kiekis, viršijantis $43 \mathrm{U} / \mathrm{ml}$, leidžia ịtarti tuberkuliozinę kilmę. Jautrumas, įvairių autorių duomenimis, siekia 60-100 proc., tačiau mažesnis rodiklis TB tikimybès neatmeta. Didesnè nei 140 pg/ml gama interferono koncentracija taip pat rodo galimą tuberkuliozinę kilmę, bet jo tyrimai nèra atliekami rutiniškai.

\section{Vaizdo tyrimai \\ Kompiuterine tomografija}

Spiralinė krūtinès ląstos kompiuterinè tomografija (KT) padeda atskirti pleuros ir plaučiuc parenchimos ligas, geriau ịvertinti tarpuplaučio limfmazgiụ pažeidimą,

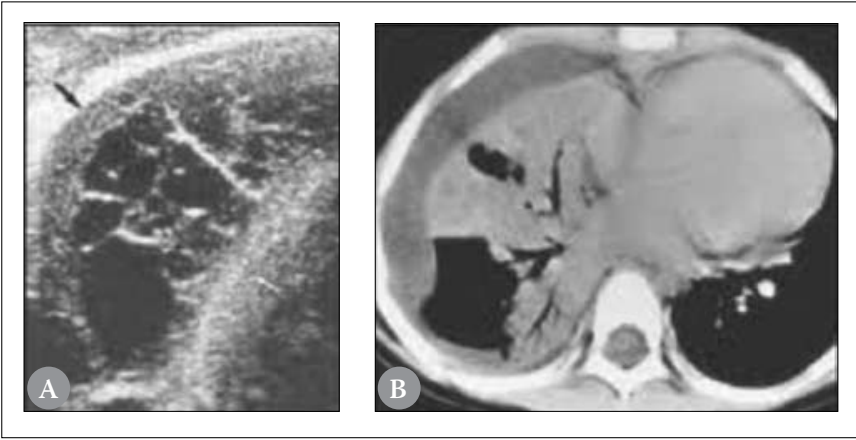

2 pav. Vieno ligonio krūtinès ląstos ultragarsinio tyrimo ir kompiuterinès tomografijos vaizdai - skystis su intarpais

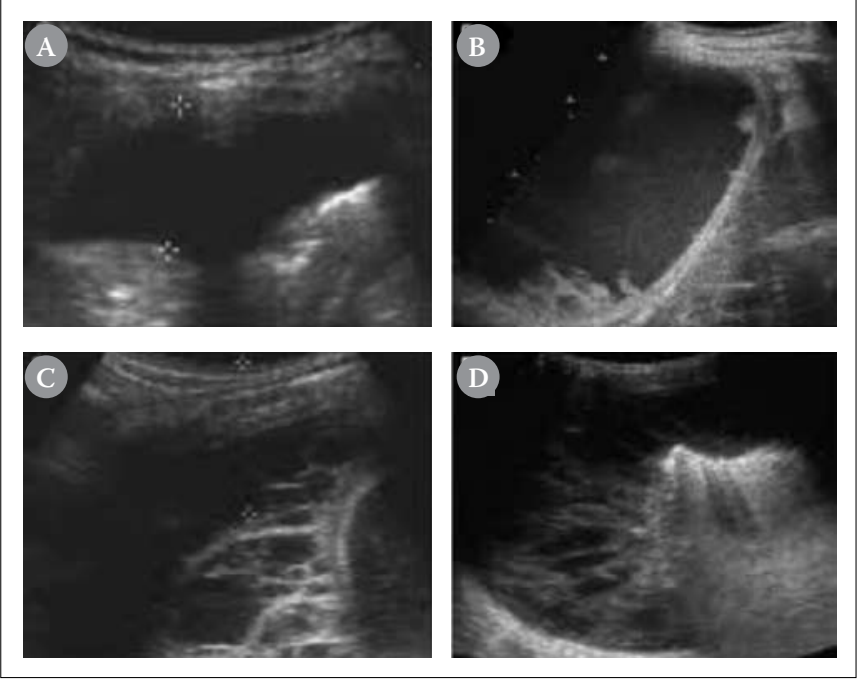

3 pav. Pleuros ertmès ultragarsinis tyrimas - didelis kiekis skysčio

plaučių parenchimos, pleuros, krūtinès ląstos sienos, kaulinių struktūrų, tarpuplaučio pokyčius, patologinio proceso lokalizaciją ir išplitimą, skysčio pleuros ertmėje pobūdị.

Kontrastinę KT rekomenduojama atlikti visiems ligoniams, kuriems pleurito priežastis nenustatyta. Tikimasi patikslinti galimą PATE i plaučių kraujagysles, navikini procesą plaučiuose ir pleuroje, tuberkuliozei būdingus pakitimus. Krūtinès ląstos kompiuterinè tomografija yra labai tikslus metodas diagnozuojant skysčio buvimą bei jo kiekị. Jeigu atlikus paprastą plaučiuc rentgenogramą itariamas skystis, reikètų tai patvirtinti arba paneigti atliekant ultragarsinị krūtinès ląstos tyrimą arba kompiuterinę tomografiją (2 pav.).

\section{Ultragarsinis tyrimas}

Ultragarsinis tyrimas (3 pav.) yra pats paprasčiausias ir prieinamiausias tyrimas skysčiui pleuros ertmèje ir jo kiekiui nustatyti, netgi sužinoti, kiek laiko jo yra pleuros ertmejje. Pagal specifiškumą jis prilygsta kompiuterinei tomografijai. Literatūroje nurodoma, kad pagal atstumą nuo plaučio iki pasieninès pleuros galima nustatyti skysčio kieki. Aišku, matuojant atstumas gali kisti, bet apytiksliam kiekiui išsiaiškinti to visiškai užtenka. Jei atstumas yra 10-20 mm skysčio kiekis - apie 200-300 ml, 
jei 2-5 mm, - apie 100-150. Ultragarsu tiriant pleuros ertmę, galima nustatyti net patị mažiausią kiekį skysčio. Pats ultragarsinis skysčio vaizdas duoda daug informacijos ir padeda numatyti tolesnio tyrimo planą. Daug fibrininių pertvaru rodo, kad skystis susikaupęs jau senokai ir spejo susiformuoti kišenès. Tokiu atveju tikètina, kad punktuojant viso skysčio pašalinti nepavyks. Pūlingam ir senam onkologiniam skysčiui būdingas labai tirštas, panašus ị tirštą sriubą, turinys su plaukiojančiais elementais. Kardiologiniai eksudatai būna dažniausiai tamsiai juodi be intarpų.

Pleuros ertmès ultragarsinis tyrimas padeda atskirti skystị pleuroje nuo fibrotorakso. Šiuo požiūriu ultragarsinis tyrimas specifiškesnis nei kompiuterinė tomografija.

Ultragarsinio tyrimo metu pažymima saugi pleuros ertmès punkcijos vieta. Punktuoti pleuros ertmę galima tik patikslinus vietą ir skysčio kiekị ultragarsiniu tyrimu arba dar geriau - kontroliuojant ultragarsu.

\section{Krūtinès ląstos rentgenografija}

Krūtinès ląstos priekineje rentgenogramoje pleuritas pastebimas, kai skysčio kiekis viršija 150-170 ml. Dažniausiai matyti šešèlis kostodiafragminiuose kampuose. Gulinčiam ant šono pacientui atliktose rentgenogramose galima matyti ir mažesnị kiekị (100-1150 ml). Rentgenogramoje galima pastebèti ir kitus pokyčius, reikalingus diagnozuojant onkologines ligas, tuberkuliozę bei kt. Tačiau, kaip minèta, dabar rentgeninis tyrimas taikomas daugiau patikros tikslu. Skysčio kilmei išsiaiškinti būtina kompiuterinè tomografija.

\section{Magnetinio rezonanso tomografija}

Magnetinio rezonanso tomografija padeda vizualizuoti audinių struktūras, krūtinès sienos struktūras ir skystị atskirti nuo auglio. Tačiau tai galima padaryti ir ultragarsinio tyrimo metu. Taigi didelès reikšmès ir pranašumo diagnozuojant ir diferencijuojant skysčio priežastis magnetinio rezonanso tomografija neturi.

\section{Fibrobronchoskopija}

Fibrobronchoskopija atliekama, jeigu atsikosejjama kraujo bei yra plaučio parenchimos pokyčių. Tyrimo metu įvertinama onkologinio ar tuberkuliozinio proceso tikimybè. Tiriant bronchų ir alveolių nuoplovas ieškoma tuberkuliozès mikobakterijų, citologiniu tyri$\mathrm{mu}$ - onkologinio proceso. Ivertinama ir aspiracijos tikimybè, nes aspiracija gali sukelti plaučio atelektazę ir antrinị hidrotoraksą. Ypač šiuo pažiūriu reikètų atkreipti dėmesi ì ligonius, sergančius CNS ligomis, demencija, patyrusius insultą ar piktnaudžiaujančius alkoholiu, narkotikais.

\section{Biopsija}

Vienas iš būdų, nustatyti skysčio pleuros ertmèje kilmę, yra pleuros biopsija. Tyrimas aktualus, kai įtariama pleuros tuberkuliozė ar onkologinis procesas. Tačiau, lyginant su torakoskopija, jos nauda gerokai mažesnè. Literatūroje nurodoma, kad, esant neigiamam citologinio tyrimo rezultatui, pleuros uždarąja adatine biopsija liga nustatyta tik 7-12 proc. atvejų. Uždarosios adatinès biopsijos efektyvumas yra geras tik tada, kai ji kontroliuojama kompiuterine tomografija. Kai KT pleuroje nustatomas sustorejjimas ar auglys, rekomenduojama atlikti pleuros perkutaninę biopsiją, o kai matyti tik skysčio - torakoskopiją. Padidèjus chirurginių procedūruc prieinamumui, neaiškiais atvejais, kai nèra kontraindikacijų, nereikètų jų vengti diagnozei patikslinti. Juolab, kad, radus onkologini procesą ar tuberkuliozę, rizika atsiperka su kaupu. Paprastai išoperuotas ligonis po 2-3 dienų jau gali būti gydomas ambulatoriškai.

\section{IDIOPATINIS EKSUDACINIS SKYSTIS}

Literatūros duomenis, netgi atlikus visus tyrimas, pakartotines pleuros ertmès punkcijas apie 20 proc. ligoniu pleuros ertmės eksudato priežasties taip ir nepavyksta nustatyti. Tais atvejais reikètų apsvarstyti kitas galimas priežastis, kai dèl ilgalaikio kontakto su asbestu sukelta gerybinè pleuros ertmès asbestozè ar ilgai vartojant nitrifurantoinus, amiodaroną atsiranda skystis pleuros ertmèje. Galimas ir hepatinis hidrotoraksas, netgi nesant skysčio pilvo ertmèje.

Rekomenduojama, nenustačius priežasties, ligonio toliau nebetirti ir stebèti šiais atvejais:

- Paciento būklè stabili;

- Nèra nepaaiškinamo svorio mažèjimo;

- Pleuros adenozino deaminazès (ADA) mažiau kaip $43 \mathrm{U} / \mathrm{ml}$ (tuberkuliozei nustatyti);

- Nèra karščiavimo;

- Pleuros ertmès skystyje limfocitų kiekis mažesnis nei 95 proc.;

- Skystis užima mažiau kaip 50 proc. vienos krūtinès ląstos pusès.

Jeigu ligonis neatitinka nurodytųjų kriterijų ar skystis atsinaujina bei yra didelè onkologinio proceso ar tuberkuliozès tikimybè, tenka pereiti prie chirurginių tyrimo metodų. Torakoskopija ir atvira torakotomija skysčio pleuros ertmèje etiologija patikslinama 92 proc. atvejų. Tuo pačiu, esant indikacijų, atliekamas ir pleuros ertmės talkavimas ertmès sklerozei sukelti. Tikimasi, kad suformuojamas dirbtinis fibrotoraksas neleis skysčiui atsinaujinti.

\section{PLEURAL EFFUSION - THERAPEUTIC PROBLEM}

\section{ARVYDAS VALAVIČIUS}

DEPARTMENT OF PULMONOLOGY KLAIPEDDA UNIVERSITY HOSPITAL

Keywords: pleural effusion, tuberculiosis, cardiiovascular decompensation, thoraconcentezis, thoracoscopia.

Summary. Management patient with pleural effusio. Diagnosis and treatment. 